\title{
HEALTH IMPACTS OF PSYCHOSOCIAL FACTORS AMONG CONSTRUCTION WORKERS: A SYSTEMATIC REVIEW
}

\author{
Khairul Fajarudin ${ }^{1}$, Dadan Erwandi ${ }^{2}$ and Abdul Kadir ${ }^{3}$ \\ Master Program of Occupational Health and Safety ${ }^{1}$ \\ Occupational Health and Safety Department, Faculty of Public Health, Universitas Indonesia ${ }^{2,3}$ \\ khairulfajarudin@gmail.com ${ }^{1}$, dadan@ui.ac.id ${ }^{2}$
}

\begin{abstract}
Psychosocial factors are one of the health determinants in construction activities that can damage physical and psychological conditions through stress mechanism. This study is intended to investigate the dominant psychosocial factors that deteriorate the health of construction workers by conducting a systematic review. The systematic review was conducted from journal articles retrieved using 3 library search engines: ProQuest, Scopus, and EBSCO, for the articles published within the years of 2010 - 2019 using keywords of "construction work or industry or labor" for population; "psychosocial" for exposure; and "health or mental or stress or disorder" for outcome. The criteria used were articles on construction workers experiencing psychosocial exposure, either physical or mental health outcomes. The search result was 123 out of 65.797 articles: 37 articles from ProQuest, 5 articles from Scopus, and 81 articles from EBSCO. Further screening was to omit duplicates, then reviewing both abstract and full-text resulted in analysis of 10 articles. There were 6 domains of psychosocial factors analyzed: psychological demand, job demand, job control, job dissatisfaction, work-family conflict, and bullying. The mental health problems identified were stress, psychological distress, presenteeism, and misuse of drugs while the physical health problems discovered were musculoskeletal disorders, increased blood pressure, increased body mass index, increased fat mass percentage, fatigue, and heat diseases. It is suggested the construction industry enhance its current work-related ill-health prevention programs by considering the salient psychosocial factors that were identified in this study so that they can minimize the deterioration of the health of their workers.
\end{abstract}

Keywords $\quad$ : Psychosocial factors, Stress, Construction Workers

\begin{abstract}
ABSTRAK
Faktor psikosial adalah salah satu determinan kesehatan di aktivitas konstruksi yang dapat merusak kondisi fisik dan psikologi melalui mekanisme stress. Studi ini bertujuan untuk menyelidiki faktor psikososial yang dominan yang menurunkan kesehatan pekerja konstruksi dengan melakukan systematic review. Systematic review dilakukan dari artikel jurnal yang diperoleh dari 3 mesin pencari perpustakaan: ProQuest, Scopus, dan EBSCO, terhadap artikel yang dipublikasikan antara tahun 2010-2019 menggunakan kata kunci "construction work atau industry atau labor" untuk populasi; "psychosocial" untuk paparan; dan "health atau mental atau stress atau disorder" untuk hasil. Kriteria yang dipakai adalah artikel penelitian pada pekerja konstruksi yang mengalami paparan psikosisal, dengan dampak baik fisik maupun mental. Pencarian menghasilkan 123 artikel dari 65.797 artikel: 37 artikel dari ProQuest, 5 artikel dari Scopus, dan 81 artikel dari EBSCO. Penyaringan lebih lanjut untuk membuang duplikat, lalu meninjau abstrak dan isi keseluruhan teks menghasilkan analisa terhadap 10 artikel. Terdapat 6 elemen faktor psikososial yang di analisa: tuntutan psikologi, tuntutan pekerjaan, kendali pekerjaan, kepuasan kerja, konflik kerja-keluarga, dan bullying. Masalah kesehatan mental yang teridentifikasi adalah stress, distress psikologi, presenteeism, dan penyalahgunaan obatobatan terlarang, sedangkan masalah kesehatan fisik yang ditemukan adalah gangguan otot-rangka, peningkatan tekanan darah, penambahan indeks massa tubuh, peningkatan persentase lemak, kelelahan dan penyakit akibat panas. Disarankan bagi industri konstruksi untuk meningkatkan program pencegahan gangguan kesehatan mereka saat ini dengan mempertimbangkan faktor psikososial yang ditemukan pada studi ini sehingga dapat menurunkan masalah kesehatan pada pekerja mereka.
\end{abstract}

Kata kunci : Faktor-faktor psikososial, Stress, Pekerja Konstruksi 


\section{INTRODUCTION}

Construction is one of the major industries playing an important role in development in every country. Construction works include activities that are high-risk in nature, and typically involve a lot of workers, high skill, long hours of work, frequent moving, and use of heavy machinery. This sector is infamous for a high level of occupational accidents and diseases. In 2019, there were 1,066 fatal work injuries of construction workers in the United States of America (Bureau of Labor Statistics, 2020). This industry also contributes 81,000 cases of work-related ill-health in Great Britain and $57 \%$ of it was associated with musculoskeletal disorders (Health and Safety Executive, 2020).

The social and organizational contexts that influence the health and well-being status of personnel in the workplace are the physical and psychosocial hazards (Cox, Griffiths, \& Rial-González, 2000). Physical hazards can directly affect health conditions (Cox et al., 2000) and this includes heat, humidity, vibration, and noise (Pacaiova \& Balazikova, 2010). Psychosocial hazards (factors) are elements of work design, management, and arrangement of work, including their social context that can endanger the physical or psychological state of the workers (Cox et al., 2000). Psychosocial factors can impact health conditions through indirect stress mechanisms. A previous study showed that stress is associated with the occurrence of injury and loss of workdays (Abbe, Harvey, Ikuma, \& Aghazadeh, 2011) as well as physical and mental illnesses such as heart problem, depression, anxiety, and behavior change such as smoking, alcohol consumption, and sleep problem (Burman \& Goswami, 2018). For companies, stress will lower productivity; increase absenteeism and presenteeism; reduce motivation; reduce job satisfaction; and weaken commitment (International Labour
Organization, 2016). It was estimated that around 500.000 workers in the United Kingdom have a stress problem (Health and Safety Executive, 2016) and the same problem also increases the US health expense by around 125-190 million dollars every year (Blanding, 2015).

This study examines psychosocial risk factors among construction workers and their impact on health, both mental and physical health. A previous similar study of psychosocial factors in the construction industry only focuses on injury outcomes (Abbe et al., 2011) or musculoskeletal disorders (Sobeih, Salem, Daraiseh, Genaidy, \& Shell, 2006). To the best of our knowledge, there is no recent study that evaluates psychosocial factors in construction workers with all possible health outcomes. The present study aims to investigate the dominant psychosocial factors that deteriorate the health of construction workers by conducting a systematic review. It is expected that the result will give readers knowledge regarding which psychosocial factors have the highest prevalence in the construction industry and their health outcomes, so better measures can be implemented to control the risk factors and mitigation can be done for the potential health impacts.

\section{METHOD}

\section{Eligibility Criteria}

The articles for this review were selected using an approach with particular study characteristics which is referred to as the PICOS approach or Population, Intervention/Exposure,

Comparison/Control, Outcome, and Study Design approach. The population selected was all construction workers. The exposure studied was psychosocial factors, with any physical or mental health outcomes. There were no comparison or control criteria for the review because we merely wanted to capture the phenomenon in the population. The study design 
included all types of studies to broaden study results.

The population for this review was construction workers, regardless of their age, sex, years of experience (including first-year workers or apprentices), role, position level, and work location (sitebased or office-based). The study type included cohort, case-control, case study, cross-sectional, Randomized Control Trial (RCT) and we exclude any conceptual or editorial comments as they have a low level of evidence. The article should also be fully published, peer-reviewed, and publication types such as book chapters, news or magazine article, and conference paper are excluded from the review. Upto-date articles are also important to ensure the knowledge from the review matches the current situation, hence we selected only articles from the last 10 years from January 1, 2010, to December 31, 2019. Articles published within this date but using older data sources (before 2010) in their analysis were also excluded. The protocol for this study was registered with PROSPERO (the registration number is: CRD42021222358)

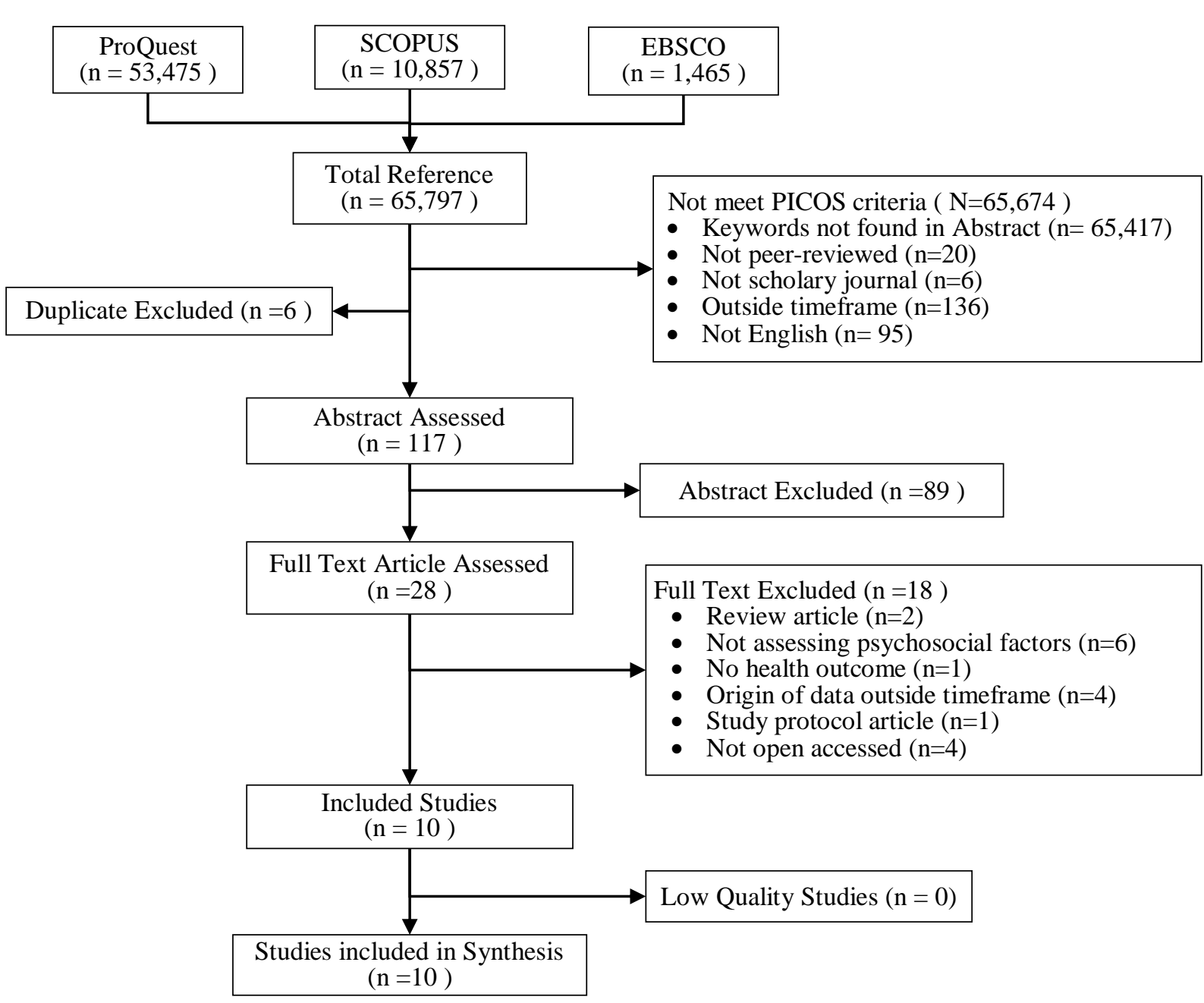

Figure 1. PRISMA Flow diagram of the study

available in English. Therefore, any other

\section{Search}

The selection approach in this study selection was performed by adopting the
Preferred Reporting Items for Systematic reviews and Meta-Analyses (PRISMA) approach (Liberati et al., 2009). As already mentioned, the study characteristics 
became the criteria for searching the literature from several journal databases using the keywords of "construction work*" or "construction industry" or "construction labo*" for Population; "psychosocial" for Exposure; and "health" or "mental" or "stress*" or "disorder" for Outcome. The wildcard (*) symbol was used to broaden search results since word variations might be used in the articles, e.g. workers, workers, labor, labor. The library search engines used were ProQuest, SCOPUS, and EBSCOhost due to their coverage which includes major databases relevant to this review, such as APA PsycArticle, Health, and Medical Collection, Healthcare Administration Database, Nursing \& Allied Health Database, Psychology Database, PTSDpubs, Publicly Available Content Database, Research Library Database in ProQuest; Academic Search Complete, Medline, and CINAHL Plus database in EBSCO.

\section{Study Bias and Quality Assessment}

The risk of bias was evaluated based on the type of study elaborated in the articles. For RCT studies, the risk of bias tool used was Chrocane collaboration's tool for assessing risk of bias (Higgins et al., 2011). The tool consists of six bias domains: Selection Bias, Performance Bias, Detection Bias, Attrition Bias,
Reporting Bias, and Other Bias. Each domain was judged with a low, unclear, and high risk of bias. For non-RCT studies, the risk of bias tool used was the Risk of Bias Assessment tool for Nonrandomized Studies (RoBANS) (Kim et al., 2013). The RoBANS tool consists of six domains: Selection of participants, Cofounding variables, Intervention (exposure) measurement, Blinding of outcome assessment, Incomplete outcome data, Selective Outcome reporting. Each domain was assessed with a low, unclear, and high risk of bias.

\section{RESULT}

There were a total of 65,797 articles found by the three library search engines. Articles found were then screened using the PICOS criteria by looking at, among others, pre-determined keywords in the abstract, peer-reviewed and scholarly journal types, timeframe, and English language. Duplicates were also omitted to result in the remaining 117 articles. These articles were then screened both for the abstract and the full text to ensure the eligibility of the article context for meeting the review objectives. Finally, 10 articles were deemed to meet the eligibility criteria for quality assessment as shown in Table 1. PRISMA flow diagram for article screening is depicted in the Figure 1.

Table 1. Risk of Bias Assessment Result

\begin{tabular}{|c|c|c|c|c|c|c|c|c|c|c|c|}
\hline \multirow{3}{*}{ No } & \multirow[b]{2}{*}{ Domain } & \multicolumn{10}{|c|}{ Author, Year } \\
\hline & & 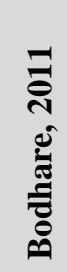 & 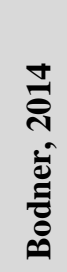 & 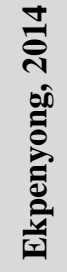 & 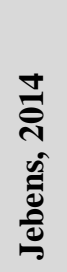 & 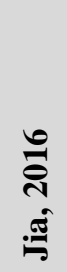 & 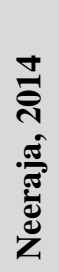 & 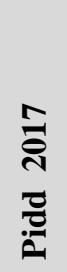 & 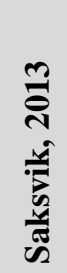 & 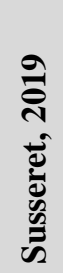 & 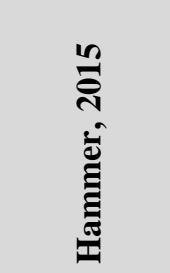 \\
\hline & $\begin{array}{l}\text { Study Type } \\
\text { (Risk of Bias Tool) }\end{array}$ & \multicolumn{9}{|c|}{$\begin{array}{l}\text { Non-RCT } \\
\text { (RoBANS) }\end{array}$} & $\begin{array}{c}\text { RCT } \\
\text { (Cochrane) } \\
\end{array}$ \\
\hline 1 & $\begin{array}{l}\text { Selection of participants/ } \\
\text { Random Sequence }\end{array}$ & - & $?$ & + & $\odot$ & $\Theta$ & - & $\odot$ & - & - & + \\
\hline 2 & Cofounding variables & + & $?$ & $\oplus$ & $\oplus$ & $\oplus$ & $\oplus$ & $?$ & + & + & RCT does \\
\hline 3 & Intervention (exposure) & + & - & + & + & + & + & ? & + & + & $\begin{array}{l}\text { not assess } \\
\text { these items }\end{array}$ \\
\hline
\end{tabular}




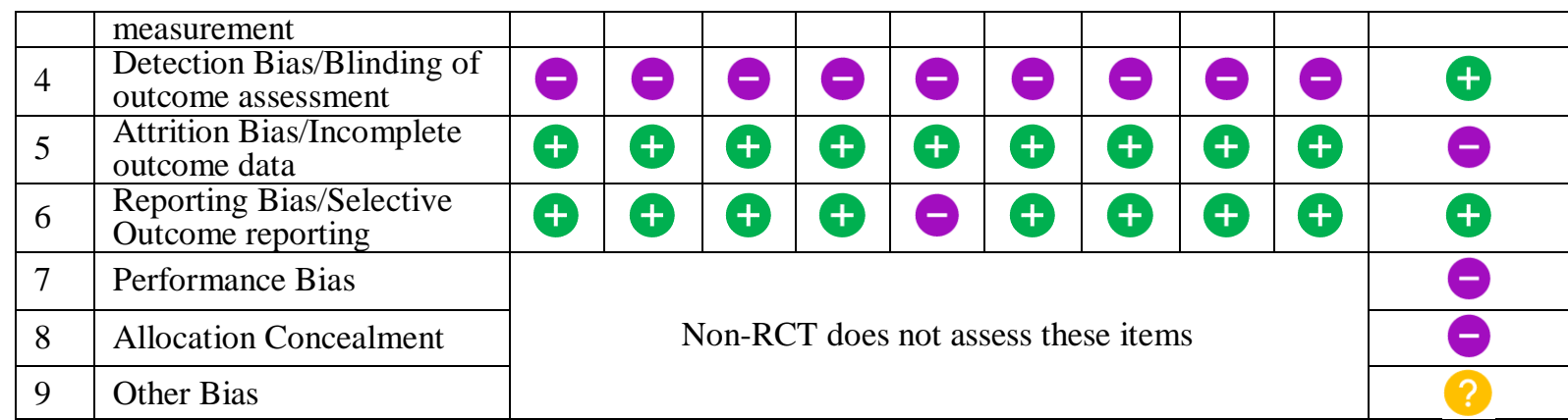

Key: Low risk of bias

High risk of bias

Unclear risk of bias

\section{Study Characteristic}

Among the 10 studies, 9 of them were cross-sectional studies while the remaining study used the RCT approach. Eight out of ten studies presented physical health outcomes: 5 studies were associated with musculoskeletal disorders (MSDs) and 3 studies described other health problems. The total number of participants was 2,758 , with a sample size ranging from 36 to 1,200 . In all studies, male participants were dominant with 3 studies had all-male participants. The lowest proportion of males in studies with mixed-gender participants was 69\%. Six studies had wide-spread participants' age, ranging between 15 to 65 years old. Three studies were dominated by the participants in the age group of 42-45 years old and one study included participants who were mostly below 21 years old. The location of participants was also widely distributed and include various places around the world with two from North-America, two from Europe, two from South-Asia, and the remainings were from Australia, Africa, East-Asia, and South-America. Table 2 lists the characteristics of the included studies.

\section{Psychosocial Factors}

Meta-analysis was not conducted for these studies because the data were highly heterogonous and the number of studies reviewed was small; thus, the narrative synthesis approach was chosen. There were only three articles that provided significance indicators $(\mathrm{P}<0.005)$ within their studies (Bodner et al., 2014; Ekpenyong \& Inyang, 2014; Neeraja, 2014), while the remainings showed varying association measurement of psychosocial factors across the population under study. We used these association indicators and subjective appraisal for selecting psychosocial factors components with a strong association for health impact/s in each study. The analysis yielded six domains of prominent psychosocial factors, i.e. psychological demand, Job demand, job control, workfamily conflict (work-life balance), job dissatisfaction, and bullying. Each of these psychosocial factors was associated with one or more health consequences, both physical and mental consequences. The conceptual framework of this study is shown in figure 2 .

Figure 2. Conceptual Framework of Psychosocial Factors and Health Outcomes in Construction

\begin{tabular}{|c|c|}
\hline \multirow{2}{*}{$\begin{array}{c}\text { Psychological } \\
\text { demand }\end{array}$} & \\
\hline & \multirow{3}{*}{$\begin{array}{l}\text { Mental health } \\
\text { problems: } \\
\text { - Stress } \\
\text { - Pscyhological } \\
\text { distress } \\
\text { - Presenteeism } \\
\text { - Misuse of drugs }\end{array}$} \\
\hline Job demand & \\
\hline Job Control & \\
\hline Job & Physical health \\
\hline & $\begin{array}{l}\text { problems: } \\
\text { • MSDs }\end{array}$ \\
\hline Work-Family & - Higher blood \\
\hline $\begin{array}{l}\text { (Work-Life } \\
\text { Balance) }\end{array}$ & $\begin{array}{l}\text { - Increase BMI } \\
\text { - Increase \% fat mass }\end{array}$ \\
\hline & - Heat illness \\
\hline
\end{tabular}




\section{Psychological Demands}

Psychological demands had an odds ratio that was 2 times higher than any other psychosocial factor for deploying MSDs in our review. This result might be because most construction workers have low education and their nature of employment is temporary or casual which puts them in poor psychosocial demand due to job insecurity, less job control, and lower bargaining position for a better salary (Ekpenyong \& Inyang, 2014). A similar result is also demonstrated in other studies (Neeraja, 2014), where it is revealed that women had a higher prevalence of MSDs compared to men participants. This result might be influenced by biological differences, different tasks or working styles, and apparent symptoms among women participants (Neeraja, 2014).

Table 2. Study Characteristics

\begin{tabular}{|c|c|c|c|c|c|}
\hline Study & $\begin{array}{l}\text { Study } \\
\text { Design }\end{array}$ & $\begin{array}{l}\text { Sample } \\
\text { size }\end{array}$ & $\begin{array}{l}\text { Psychosocial } \\
\text { factor }\end{array}$ & Health outcome & $\begin{array}{c}\text { Association Result } \\
\text { (Mean, Odds Ratio, } \\
\text { Prevalence Ratio, } \\
\text { Correlation (r), etc) }\end{array}$ \\
\hline $\begin{array}{l}\text { Bodhare et al., } \\
2011\end{array}$ & $\begin{array}{l}\text { Cross- } \\
\text { Sectional }\end{array}$ & 211 & $\begin{array}{l}\text { Job } \\
\text { dissatisfaction } \\
\text { (JD), lack of } \\
\text { job control (JC) }\end{array}$ & $\begin{array}{l}\text { Musculoskeletal } \\
\text { disorders (MSDs) }\end{array}$ & $\begin{array}{l}\text { mean } \pm \mathrm{SD} \text { to } \mathrm{MSDs} \text { for } \\
\mathrm{JD}=11.35 \pm 0.59 ; \mathrm{JC}=8.8 \\
\pm 0.47\end{array}$ \\
\hline $\begin{array}{l}\text { Bodner et al., } \\
2014\end{array}$ & $\begin{array}{l}\text { Cross- } \\
\text { Sectional }\end{array}$ & 349 & $\begin{array}{l}\text { Work-family } \\
\text { conflict (WF), } \\
\text { job decision } \\
\text { latitude (JL), } \\
\text { job demand } \\
(\mathrm{JM}) \text {, perceived } \\
\text { organization } \\
\text { support (PO) }\end{array}$ & $\begin{array}{l}\text { Physical health } \\
\text { composite } \\
\text { Heart rate }(\mathrm{PH}), \\
\text { Body Mass } \text { Index } \\
\text { (BM), Fat Mass } \\
\text { percentage (FM), } \\
\text { Missed work due } \\
\text { to injury (MW), } \\
\text { Diastolic blood } \\
\text { pressure (DB), } \\
\text { Pain, discomfort } \\
\text { on body parts } \\
\text { (PD) }\end{array}$ & $\begin{array}{l}\text { From the bivariate } \\
\text { relationship matrix, there } \\
\text { was a positive association } \\
\text { between WF, JL, and DB, } \\
\text { MW, PD; a negative } \\
\text { association between JL, PO } \\
\text { and HR, FM, BM, MW, } \\
\text { PD }\end{array}$ \\
\hline $\begin{array}{l}\text { Ekpenyong \& } \\
\text { Inyang, } 2014\end{array}$ & $\begin{array}{l}\text { Cross- } \\
\text { Sectional }\end{array}$ & 1.200 & $\begin{array}{l}\text { Psychological } \\
\text { demand \& } \\
\text { mental load } \\
\text { (PD), Job } \\
\text { Insecurity (JI) }\end{array}$ & $\begin{array}{l}\text { Musculoskeletal } \\
\text { disorders (MSDs) }\end{array}$ & $\begin{array}{l}\text { Logistic Regresion analysis } \\
\text { showed Odds Ratio to } \\
\text { MSDs for PD }=1.59, \mathrm{JI}= \\
1.42\end{array}$ \\
\hline $\begin{array}{l}\text { Hammer et al., } \\
2015\end{array}$ & $\begin{array}{l}\text { Randomi } \\
\text { ze } \\
\text { Control } \\
\text { Trial }\end{array}$ & 227 & $\begin{array}{l}\text { Work-life } \\
\text { balance }\end{array}$ & Blood pressure & $B=-2.15, p=0.038$ \\
\hline $\begin{array}{l}\text { Jebens et al., } \\
2014\end{array}$ & $\begin{array}{l}\text { Cross- } \\
\text { Sectional }\end{array}$ & 87 & $\begin{array}{lr}\text { Job } & \text { control } \\
\text { (flexible } & \text { rest } \\
\text { period) } & \end{array}$ & $\begin{array}{l}\text { Neck, shoulder, } \\
\text { upper back pain }\end{array}$ & $\begin{array}{l}\text { QPSNordic mean } \pm \text { SD } \\
\text { score was low }(1.2 \pm 1.3) \\
\text { on laborers with fixed rest } \\
\text { period with little } \\
\text { possibilities for change }\end{array}$ \\
\hline Jia et al., 2016 & $\begin{array}{c}\text { Mix } \\
\text { (cross- } \\
\text { section \& } \\
\text { interview } \\
\quad \text { ) }\end{array}$ & 36 & $\begin{array}{l}\text { Workload, } \\
\text { work-pace }\end{array}$ & $\begin{array}{l}\text { Fatigue, } \\
\text { illness }\end{array}$ & $\begin{array}{l}\text { No measurement was } \\
\text { conducted. Observation } \\
\text { study revealed long } \\
\text { working hours and lack of } \\
\text { rest causing fatigue and } \\
\text { heat illness }\end{array}$ \\
\hline
\end{tabular}




\begin{tabular}{|c|c|c|c|c|c|}
\hline Study & $\begin{array}{l}\text { Study } \\
\text { Design }\end{array}$ & $\begin{array}{l}\text { Sample } \\
\text { size }\end{array}$ & $\begin{array}{l}\text { Psychosocial } \\
\text { factor }\end{array}$ & Health outcome & $\begin{array}{l}\text { Association Result } \\
\text { (Mean, Odds Ratio, } \\
\text { Prevalence Ratio, } \\
\text { Correlation (r), etc) }\end{array}$ \\
\hline $\begin{array}{l}\text { Machado } \\
\text { Susseret et al., } \\
2019\end{array}$ & $\begin{array}{l}\text { Mix } \\
\text { (cross- } \\
\text { section \& } \\
\text { interview } \\
\quad \text { ) }\end{array}$ & 275 & $\begin{array}{l}\text { Job insecurity, } \\
\text { long working } \\
\text { hour (Effort- } \\
\text { Reward } \\
\text { Imbalance) }\end{array}$ & Low back pain & Prevalence Ratio $=1.43$ \\
\hline Neeraja, 2014 & $\begin{array}{l}\text { Mix } \\
\text { (cross- } \\
\text { section \& } \\
\text { interview } \\
\quad \text { ) }\end{array}$ & 220 & $\begin{array}{l}\text { Psychological } \\
\text { demand (PD), } \\
\text { job } \\
\text { dissatisfaction } \\
\text { (JD) }\end{array}$ & $\begin{array}{l}\text { Neck, shoulder, } \\
\text { upper back MSDs }\end{array}$ & $\begin{array}{l}\text { Logistic Regresion analysis } \\
\text { showed Odds Ratio to } \\
\text { MSDs for PD }=1.69, \mathrm{JD}= \\
1.68\end{array}$ \\
\hline $\begin{array}{l}\text { Pidd et al, } \\
2017\end{array}$ & $\begin{array}{l}\text { Cross- } \\
\text { Sectional }\end{array}$ & 169 & Bullying & $\begin{array}{l}\text { Psychological } \\
\text { distress (PS), Jobs } \\
\text { Stress (JS), use of } \\
\text { drugs (UD), } \\
\text { presenteeism (PT) }\end{array}$ & $\begin{array}{l}\text { Correlation matrix showed } \\
\left.\text { a correlation ( } \mathrm{r}_{\mathrm{s}} \text { value }\right) \\
\text { between bullying and PS = } \\
0.51 ; \mathrm{JS}=0.62 ; \quad \mathrm{UD}=0.17 \text {; } \\
\mathrm{PT}=0.37\end{array}$ \\
\hline $\begin{array}{l}\text { Saksvik et al., } \\
2013\end{array}$ & $\begin{array}{l}\text { Cross- } \\
\text { Sectional }\end{array}$ & 125 & Job demand & $\begin{array}{ll}\begin{array}{l}\text { Mental } \\
\text { reaction } \\
\text { stress (SR) }\end{array} & \text { health } \\
\end{array}$ & $\begin{array}{l}\text { The correlation matrix } \\
\text { showed a correlation }\left(r_{\mathrm{S}}\right. \\
\text { value) between job demand } \\
\text { and } M R=-0.44, S R=0.44\end{array}$ \\
\hline
\end{tabular}

\section{Job Demands}

Job demand among construction workers correlates with more mental health problems and higher stress (Saksvik et al., 2013). The job demand increases due to over-commitment at work and moderated by rewards. Both later variables are also known as part of the effort-reward imbalance (ERI) components which, if not adjusted properly, may lead to low back pain (N Machado Susseret et al., 2019). Other health conditions are also affected by job demand as it is demonstrated that job demand is positively associated with diastolic blood pressure, work absence, and experience of pain or discomfort (Bodner et al., 2014). Heat-related illnesses, particularly during hot days, are also associated with high job demand through higher metabolism mechanisms in the body. High job demand that includes heavy physical workloads or continuous works without break to gain financial incentive eventually will lead to fatigue (Jia et al., 2016).
Lack of job control was found to be associated with MSDs (Bodhare et al., 2011), particularly in women (Neeraja, 2014). An example of job control is the flexibility of work schedule and length of rest, which are considered important parts for willingness to continue working (Jebens et al., 2014). Organizations that support individual autonomous adaptation can help workers to regulate their metabolic body mechanisms to avoid heatrelated illnesses (Jia et al., 2016). In general, workers with job decision latitude have a better health condition, indicated by lower Body Mass Index (BMI), fat mass percentage, heart rate, and absence from work due to injury (Bodner et al., 2014).

\section{Job Dissatisfaction}

Job dissatisfaction among construction workers has a higher probability of creating upper limb MSDs (Neeraja, 2014). Again, ERI factors may be involved in this job dissatisfaction, because when skilled workers are involved, they often do not practice their specialty and, thus, their 
supervisor does not appreciate their work and skill (Jebens et al., 2014). Workers who do not have a working contract and working more than 44 hours per week also have a high ERI score (N Machado Susseret et al., 2019).

\section{Work-Family Conflict (Work-Life Balance).}

Work-family conflict is associated with poor overall health conditions with several attributes, such as diastolic blood pressure, increase BMI, pain or discomfort, and missing work because of injury (Bodner et al., 2014). Modifying this factor is also epidemiologically demonstrated as leading to positive results, which is done by improving supervisor support, team effectiveness, and safety communication. When this modification is in place, the participants in the intervention group have better blood pressure, which is an important impact as increased blood pressure is known as a risk factor for cardiovascular disease (Hammer et al., 2015).

\section{Bullying}

A high level of workplace bullying, particularly on younger workers, was strongly associated with high psychological distress and job stress. This condition led to a high level of presenteeism, and more frequent use of illegal drugs (Pidd et al., 2017). The transition from school to work environment to these young workers can be challenging and very demanding.

\section{DISCUSSION}

This review study gives insight to the reader regarding the most contributing psychosocial factors among construction workers based on several recent studies. Knowledge gained from this study will be useful for organizations, employers, and practitioners to adjust their policy and strategy in creating a healthier workplace. There are six major psychosocial factors highlighted: psychological demand, job demand, job control, work-family conflict (work-life balance), job dissatisfaction, and bullying.

Two stress models that can be used to examine the result from this study are the effort-reward imbalance model by Siegrist (2002) and the job demand-control model by Karasek (1979) The effort-reward imbalance framework assumes a relationship between health and wellbeing status of a person from the reciprocity of effort and expected reward whereas a problem will occur when there is an imbalance between these two. Personal factors, such as overcommitment, may play an important role for certain participants such as in immigrant workers in Saksvik PØ, Dahl-Jørgensen C, Tvedt SD (2013) study, but external factors such as low skill work and short term contract are also observed in most studies, which is typical in the construction industry. From a different perspective, the job demandcontrol model offers mutual interactions between the demand of the task and control adhered to the workers. This model conceptualized job strain as a result of high job demand and low job decision latitude. The current study shows that the most contributing factors came from the high demand for workload, mental aspects, and the job itself. Health problems then emerge when such demand is paired with insufficient job control, such as lack of working flexibility.

Job demand is any physical, psychological, social, and organizational work characteristics that require ongoing physical and/or psychological efforts (Schaufeli \& Bakker, 2004). The association between high job demand and various physical and mental health problems in construction workers is consistent with previous studies done by Boschman et al. (2013). Our review found that job demand is the highest predictor for stress (Saksvik et al., 2013). Several 
previous studies examined the differences in job demand characteristics between low-skill labors and supervisor workers. The low-skill labors such as the bricklayers experience high job demand from excessive job quantity and work speed, while the supervisors have a high job demand from spending longer work hours. The job demand becomes the strongest predictor for depression among low-skill labors. For supervisors, however, their mental health problem does not only comes from high job demand but also due to low job control and social support. This suggests that the nature of job demand and job control conflict may vary across job levels in the construction industry.

From the definition of job demand above, it can be inferred that psychological demand is also part of job demand that focuses on the mental or psychological requirements to complete the task. High psychological demand and low job control job is categorized as high strain, and Ostry AS, Kelly S, Demers PA, et al. (2003) found this condition to be associated with a poor health condition. Although Karasek et al. (1998) considered the construction laborer has low psychological demand, but the current study found psychological demand as a dominants predictor of MSDs (Ekpenyong \& Inyang, 2014; Neeraja, 2014). The current study, however, did not found any mental health outcomes as a result of psychological demand. A strong association between psychological demand and MSDs found in the current study is not supported by a previous study done by Kusmasari and Yassierli (2019) who found no significant relationship between these two variables. However, the result of the previous study can be argued since it only includes a small sample size which indicates high variability and less power of study.

Job control is the degree to which a job enables independence, autonomy, and discretion to schedule work, make decisions, and choose the methods used to perform tasks (Morgeson \& Humphrey,
2006). Contrary to expectation, the job control variables in this review were found to only have associations with physical health problems (upper MSDs) with no association with mental health outcomes (Bodhare et al., 2011; Jebens et al., 2014). The review finding is consistent with the finding in a study done by Bowen $\mathrm{P}$, Edwards P, Lingard H, Cattell K (2014) that found none of the individual job control variables is a significant predictor of work stress. From the job demand and job control variable discussion above, we can conclude that the job-demand-control model is only partially supported in this review study.

Job dissatisfaction deals with an employee's interest in a specific job which encompasses intrinsic and extrinsic job dissatisfaction (Markowitz \& Wuest, 2013). The intrinsic factors include the personal preference of the job while the extrinsic factors relate to the work environment such as salary, colleague, and management (Markowitz \& Wuest, 2013). The current study found job dissatisfaction as the strongest predictor for MSDs (Neeraja, 2014) and, among those who have MSDs, the average score of anxiety, depression, and stress was high (Bodhare et al., 2011). The positive association between job dissatisfaction and MSDs is supported by a previous study done by Navarro-Abal Y, Sáenz-De la Torre LC, Gómez-Salgado J, Climent-Rodríguez JA (2018) that demonstrated a negative correlation between job satisfaction and body pain, and perceived general health status.

The present study shows work-tofamily conflict as another psychosocial factor, especially in a highly demanding situation like the construction industry. The work-family conflict occurs due to the effort to balance demands which oftentimes conflicting between work demands and family-life-demands, including things that may not be related to work (Riggio, 2018). As highlighted in other studies (Lingard \& Francis, 2006), 
work-family conflict in the construction industry can cause emotional exhaustion (burnout) and the effect is moderated by practical support from co-workers and supervisors. This previous study indicates supervisor criticism of their subordinate's family responsibility is associated with high emotional exhaustion. It is suggested that the company should provide specific sensitivity training for their supervisors to focus on the organization's policy and procedures to accommodate employee's responsibility to their families and in which situation the practical support should be given. This previous study is consistent with literature findings in the current study (Hammer et al., 2015) which emphasized additional training on worklife conflict and safety communication to the supervisor may help workers to reduce work-family conflict and improve health conditions.

Bullying and its association with various mental health problems and alcohol and drug abuse have been explored in previous studies (Tiwary et al., 2013; Vartia, 2001). Bullying itself can be manifested in many forms, such as assaulting one's private life or judging one's work wrongly (Vartia, 2001). These previous studies showed that bullying among construction workers is triggered by superiors. This situation becomes a contributing factor to anxiety and frustration. In the context of superiority, the bullying victims are the subordinates or juniors, and this group is mostly represented by young workers. Hence, results from the previous studies are consistent with the current review study which shows a high prevalence of bullying to young construction workers that leads to job stress, psychological distress, and drug abuse.

Body pain and MSDs or discomfort are some of the most highlighted health outcomes caused by the psychosocial factors of this study. A similar study conducted by Sobeih TM, Salem O, Daraiseh N, et al. (2006) gives a correlation between psychosocial factors and MSDs in construction workers. A previous study found that the most contributing psychosocial factors for MSDs are low job satisfaction followed by high perceived job stress, high job demand, and low job control, which is consistent with the current study result. In addition to that, our study gives a broader health impact from psychosocial factors and presents more recent evidence. Psychosocial factors, however, may not play a major role for MSD compared to other physical factors such as awkward position or awkward movements as shown in some literature of current studies (Bodhare et al., 2011; Ekpenyong \& Inyang, 2014). Nevertheless, it is important to highlight the psychosocial factors as one of the contributing factors to MSDs since the prevalence is apparent.

Other health problem outcomes identified in this review, such as increased blood pressure, increased BMI, and increased mass percentage, are risk factors for various diseases, including cardiovascular disease (CVD) (Centers for Disease Control and Prevention, 2019). This finding aligns with findings of a previous review study that examines the direct association between psychosocial factors, such as high job demand, low control, lack of social support, and CVD (Everson-Rose \& Lewis, 2005). The current study also shows that intervening psychosocial factors in the workplace such as supporting supervisors and better communication will improve the worker's physical health status (Hammer et al., 2015). With this intervention, blood pressure is reduced and, eventually, the risk of CVD and other diseases also declines.

The present study gives a broad range of quality assessment, but still within an acceptable level overall. There are 2 major biases identified from the assessment: selection bias and detection bias. Selection bias occurs from a non-random selection of participants that may affect the study 
results. Most samples were selected using particular criteria, such as supervisor recommendation, curch connection, age, or years of working experience. Detection bias occurs when the participants are not blinded from the study outcomes, which is somewhat inevitable due to the nature of most studies that capture participant's perceptions with high subjectivity.

\section{Limitation}

Psychosocial factors in the work environment have been discussed in many articles including a study by Cox et al. (2000) becomes the main reference. This study elaborates the stressor into two domains: job context and job content. Each of them is then cascaded into several elements. This review study, however, has not able to encompass all of those elements due to the small numbers of study references. This is possibly due to the inclusion criteria that are too narrow in terms of keywords for abstract screening, exclusion of some studies that use older reference data, and the use of only 3 library search engine databases.

Almost all studies identified in this review use the cross-sectional approach which is known for its weakness in difficulties to draw a conclusion based on causal inference. The methods used are mostly ordinal Likert scales; hence, the association between variables could not be compared directly using the same and typical measurements such as odds ratio and may need further analysis such as using logistic regression. The study also has not considered individual characteristics as predictors of stress, such as a person with type-A or type-B.

\section{CONCLUSION}

Construction workers are prone to various psychosocial factors within their work environment that could impact their healths. The result from current the study shows that there are six predominant domains of psychosocial factors that play important roles in a worker's health status, namely psychological demands, job demand, job control, job dissatisfaction, work-family conflict (work-life balance), and bullying. Mental health impacts identified include stress, psychological distress, presenteeism, and drug abuse. Physical health impact includes MSDs, increase heart rate, increase BMI, increase fat mass, fatigue, and heat illness. Crosssectional studies dominate the studies on psychosocial factors and their impacts on health outcomes. The present study will give organizations knowledge on the area of psychosocial hazards that they need to handle and focus on to minimize deterioration of health among workers. This study also suggests construction industry reinforces their existing workrelated ill-health prevention program by incorporating the psychosocial factors identified in this study.

\section{ACKNOWLEDGEMENT}

The authors would like to thank the Occupational Health and Safety Department, Faculty of Public Health Universitas Indonesia for their support during completing this study.

\section{REFERENCES}

Abbe, O. O., Harvey, C. M., Ikuma, L. H., \& Aghazadeh, F. (2011). Modeling the relationship between occupational stressors, psychosocial/physical symptoms and injuries in the construction industry. International Journal of Industrial Ergonomics, 41(2), 106-117. https://doi.org/10.1016/j.ergon.2010.1 2.002

Blanding, M. (2015, January 26). Workplace Stress Responsible For Up To \$190B In Annual U.S. Healthcare Costs. Retrieved June 24, 2020, from https://www.forbes.com/sites/hbswor kingknowledge/2015/01/26/workplac e-stress-responsible-for-up-to-190- 
billion-in-annual-u-s-heathcarecosts/\#81cb943235a2

Bodhare, T., Valsangkar, S., \& Bele, S. (2011). An epidemiological study of work-related musculoskeletal disorders among construction workers in Karimnagar, Andhra Pradesh. Indian Journal of Community Medicine, 36(4), 304-307. https://doi.org/10.4103/09700218.91420

Bodner, T., Kraner, M., Bradford, B., Hammer, L., \& Truxillo, D. (2014). Safety, health, and well-being of municipal utility and construction workers. Journal of Occupational and Environmental Medicine, 56(7), 771778.

https://doi.org/10.1097/JOM.0000000 000000178

Boschman, J. S., van der Molen, H. F., Sluiter, J. K., \& Frings-Dresen, M. H. W. (2013). Psychosocial work environment and mental health among construction workers. Applied Ergonomics, 44(5), 748-755. https://doi.org/10.1016/j.apergo.2013. 01.004

Bowen, P., Edwards, P., Lingard, H., \& Cattell, K. (2014). Occupational stress and job demand, control and support factors among construction project consultants. International Journal of Project Management, 32(7), 1273-1284. https://doi.org/10.1016/j.ijproman.20 14.01.008

Bureau of Labor Statistics. (2020). National Census of Fatal Occupational Injuries in 2019. Retrieved from https://www.bls.gov/news.release/pdf /cfoi.pdf

Burman, R., \& Goswami, T. G. (2018). A Systematic Literature Review of Work Stress. International Journal of Management Studies, V(3(9)), 112. https://doi.org/10.18843/ijms/v5i3(9)/ 15

Centers for Disease Control and
Prevention. (2019, December 9). Know Your Risk for Heart Disease. Retrieved January 6, 2021, from https://www.cdc.gov/heartdisease/risk _factors.htm

Cox, T., Griffiths, A., \& Rial-González, E. (2000). Research on Work-related Stress. In Safety And Health. Luxembourg: Office for Official Publications of the European Communities.

Ekpenyong, C. E., \& Inyang, U. C. (2014). Associations between worker characteristics, workplace factors, and work-related musculoskeletal disorders: A cross-sectional study of male construction workers in Nigeria. International Journal of Occupational Safety and Ergonomics, 20(3), 447-462. https://doi.org/10.1080/10803548.201 4.11077057

Everson-Rose, S. A., \& Lewis, T. T. (2005). Psychosocial factors and cardiovascular diseases. Annual Review of Public Health, 26, 469500.

https://doi.org/10.1146/annurev.publh ealth.26.021304.144542

Hammer, L. B., Truxillo, D. M., Bodner, T., Rineer, J., Pytlovany, A. C., \& Richman, A. (2015). Effects of a workplace intervention targeting psychosocial risk factors on safety and health outcomes. BioMed Research International, 2015. https://doi.org/10.1155/2015/836967

Health and Safety Executive. (2016). Health Safety Executive 2015-16. Retrieved from http://www.hse.gov.uk/statistics/over all/hssh1516.pdf?pdf=hssh1516

Health and Safety Executive. (2020). Construction statistics in Great Britain, 2020. 1-20. Retrieved from http://www.hse.gov.uk/statistics/indu stry/construction.pdf

Higgins, J. P. T. T., Altman, D. G., Gøtzsche, P. C., Jüni, P., Moher, D., Oxman, A. D., ... Sterne, J. A. C. C. 
(2011). The Cochrane Collaboration's tool for assessing risk of bias in randomised trials. BMJ (Online), 343(7829), 1-9. https://doi.org/10.1136/bmj.d5928

International Labour Organization. (2016). Workplace Stress: a collective challenge. In Ilo. Retrieved from https://www.ilo.org/global/topics/safe ty-and-health-at-work/resourceslibrary/publications/WCMS_466547/1 ang--

en/index.htm\%0Ahttp://www.ilo.org/ africa/mediacentre/news/WCMS_477712/lang-en/index.htm

Jebens, E., Medbø, J. I., Knutsen, O., Mamen, A., \& Veiersted, K. B. (2014). Association between perceived present working conditions and demands versus attitude to early retirement among construction workers. Work, 48(2), 217-228. https://doi.org/10.3233/WOR-141863

Jia, Y. A., Rowlinson, S., \& Ciccarelli, M. (2016). Climatic and psychosocial risks of heat illness incidents on construction site. Applied Ergonomics, 53, 25-35. https://doi.org/10.1016/j.apergo.2015. 08.008

Karasek, R., Brisson, C., Kawakami, N., Houtman, I., Bongers, P., \& Amick, B. (1998). The Job Content Questionnaire (JCQ): an instrument for internationally comparative assessments of psychosocial job characteristics. Journal of Occupational Health Psychology, 3(4), 322-355. https://doi.org/10.1037/10768998.3.4.322

Kim, S. Y., Park, J. E., Lee, Y. J., Seo, H. J., Sheen, S. S., Hahn, S., ... Son, H. J. (2013). Testing a tool for assessing the risk of bias for nonrandomized studies showed moderate reliability and promising validity. Journal of Clinical Epidemiology, 66(4), 408414. https://doi.org/10.1016/j.jclinepi.2012 .09 .016

Kusmasari, W., \& Yassierli. (2019). Psychosocial Risk Factors for Musculoskeletal Symptoms of Construction Workers. IOP Conference Series: Materials Science and Engineering, 598(1). https://doi.org/10.1088/1757899X/598/1/012112

Liberati, A., Altman, D. G., Tetzlaff, J., Mulrow, C., Gøtzsche, P. C., Ioannidis, J. P. A., ... Moher, D. (2009). The PRISMA statement for reporting systematic reviews and meta-analyses of studies that evaluate health care interventions: explanation and elaboration. In Journal of clinical epidemiology (Vol. 62). https://doi.org/10.1016/j.jclinepi.2009 .06 .006

Lingard, H., \& Francis, V. (2006). Does a supportive work environment moderate the relationship between work-family conflict and burnout among construction professionals? Construction Management and Economics, 24(2), 185-196. https://doi.org/10.1080/14697010500 226913

Machado Susseret, Nestor, Briceno-Ayala, L., \& Radon, K. (2019). Prevalence of low back pain in migrant construction workers in Mar del Plata, Argentina. American Journal of Industrial Medicine, 62(9), 777-782. https://doi.org/10.1002/ajim.23016

Markowitz, J., \& Wuest, E. (2013). Encyclopedia of Behavioral Medicine. Encyclopedia of Behavioral Medicine. https://doi.org/10.1007/978-1-44191005-9

Morgeson, F. P., \& Humphrey, S. E. (2006). The Work Design Questionnaire (WDQ): Developing and validating a comprehensive measure for assessing job design and the nature of work. Journal of Applied Psychology, 91(6), 1321- 
1339. https://doi.org/10.1037/00219010.91.6.1321

Navarro-Abal, Y., Sáenz-De la Torre, L. C., Gómez-Salgado, J., \& ClimentRodríguez, J. A. (2018). Job satisfaction and perceived health in Spanish construction workers during the economic crisis. International Journal of Environmental Research and Public Health, 15(10). https://doi.org/10.3390/ijerph1510218 8

Neeraja,

$\mathrm{T}$.

(2014)

The_Factors_Associated_with_MSDs .PDF. J.Hum.Ergol., 43(January 2013), 1-8.

Ostry, A. S., Kelly, S., Demers, P. A., Mustard, C., \& Hertzman, C. (2003). A comparison between the effortreward imbalance and demand control models. 9, 1-9. https://doi.org/10.1186/1471-2458-310

Pacaiova, H., \& Balazikova, M. (2010). Assessment of Psychosocial Risks at Work. DAAAM International Scientific Book 2010, 347-356. https://doi.org/10.2507/daaam.sciboo k.2010.33

Pidd, K., Duraisingam, V., Roche, A., \& Trifonoff, A. (2017). Young construction workers: substance use, mental health, and workplace psychosocial factors. Advances in Dual Diagnosis, 10(4), 155-168. https://doi.org/10.1108/ADD-082017-0013

Riggio, R. E. (2018). Introduction to Industrial / Organizational Psychology (7th ed.). New York and London: Routledge.

Robert A. Karasek, J. (1979). Job demands, job decision latitude, and mental strain: Implication for job redesign. Administrative Science Quarterly, 24(2), 285-308.

Saksvik, P. Ø., Dahl-Jørgensen, C., \& Tvedt, S. D. (2013). Migrant Labor in the Workforce. Journal of Identity and Migration Studies, 7(1), 95-
110,132-133. Retrieved from https://search.proquest.com/scholarlyjournals/migrant-labor-

workforce/docview/1432709458/se-

2? accountid $=17242$

Schaufeli, W. B., \& Bakker, A. B. (2004). Job demands, job resources, and their relationship with burnout and engagement: A multi-sample study. Journal of Organizational Behavior, 25(3), 293-315. https://doi.org/10.1002/job.248

Siegrist, J. (2002). Effort-reward imbalance at work and health. Research in Occupational Stress and Well Being, 2, 261-291. https://doi.org/10.1016/S14793555(02)02007-3

Sobeih, T. M., Salem, O., Daraiseh, N., Genaidy, A., \& Shell, R. (2006). Psychosocial factors and musculoskeletal disorders in the construction industry: A systematic review. Theoretical Issues in Ergonomics Science, 7(3), 329-344. https://doi.org/10.1080/14639220500 090760

Tiwary, G., Gangopadhyay, P. K., Biswas, S., Nayak, K., Chakraborty, D., \& Halder, L. C. (2013). Psychosocial stress of the building construction workers. Human Biology Journal, 2(3), 207-222.

Vartia, M. A.-L. (2001). Consequences of workplace bullying with respect to the well-being of its targets and the observers of bullying. Scandinavian Journal of Work, Environment \& Health, 27(1), 63-69. Retrieved from http://www.jstor.org/stable/40967116 